\title{
Investigating the effectiveness of behavioral therapy tactics training in improving and increasing social communication and social interaction in students
}

\author{
Masume Kalantari ${ }^{1}$, Reza Abedi ${ }^{2}$, Mohammad Tahan ${ }^{3}$ \\ 1-PhD in Psychology and Exceptional Children Education, Department of Psychology, Central Tehran Branch, \\ Islamic Azad University, Tehran, Iran (Corresponding Author). $\quad$ E-mail: m.kalantari.1987@gmail.com \\ 2- Msc, Department of Psychology, Kashmar Branch, Islamic Azad University, Kashmar, Iran. \\ 3- lecturer, young Researchers and Elite Club, Birjand Branch, Islamic Azad University, Birjand, Iran.
}

Received: 05/07/2020

Accepted: 19/08/2020

\begin{abstract}
Introduction: Children with autism spectrum disorder have many problems with social skills.

Aim: The aim of this study was to investigate the effectiveness of behavioral therapy tactics training in improving and increasing social communication and social interaction in autism students.

Method: This study was performed by a semi-experimental method of pre-test and post-test with a control group. The statistical population included all students with autism with 7 to 12 years of age who referred to the Tolo Center for Disorders in Ghaeat in 2018. Out of them, 16 autism students were selected by available sampling method. Subjects underwent 9 sessions of behavioral therapy tactics based on the ABA protocol (for 2 months). The research tool was Gilliam Autism Scale (Garz-3) (2014), which was completed before and after the intervention by the parents of the students. The collected data were analyzed using SPSS software version 22 and inferential statistics, correlation coefficient and t-test.

Results: The results showed that behavioral therapy techniques led to improvement and increased social interaction and social interaction in autism students $(\mathrm{P}<0.05)$.

Conclusion: Therefore, it can be concluded that behavioral therapy techniques can be an effective way to improve the capacity and improve students in the self. This in itself confirms that these students should not be left alone without a well-codified curriculum that fits the needs of each child.
\end{abstract}

Keywords: Behavioral therapy techniques, Social communication, Social interaction, Autism students

\footnotetext{
How to cite this article : Kalantari M, Abedi R, Tahan M. Investigating the effectiveness of behavioral therapy tactics training in improving and increasing social communication and social interaction in students. Shenakht Journal of Psychology and Psychiatry. $2020 ; 7$ (4): $42-53$.URL: http://shenakht.muk.ac.ir/article-1-815-en.pdf
}

Copyright $(2018$ the Author (s). Published by Kurdistan University of Medical Sciences. This is an open access article distributed under the terms of the Creative Commons Attribution-Non Commercial License 4.0 (CCBY-NC), where it is permissible to download, share, remix, transform, and buildup the work provided it is properly cited. The work cannot be used commercially without permission from the journal. 


\title{
بررسى اثربخشى آموزش تكتيكهاى رفتاردر مانى در بهبودى و افزايش ارتباط اجتماعى و تعامل اجتماعى در دانش آموزان درخودمانده
}

\author{
معصومه كلانترى'، رضا عابدى '، محمد طحان \\ ا.دكترى تخصصى روان شناسى و آموزش كود كان استثنايى، گروه روانشناسى، واحد تهران مركزى، دانشخاه آزاد اسلامى، تهران، ايران (مولف مسئول). \\ ايميل: m.kalantari.1987@gmail.com \\ r. كارشناس ارشد، گروه روانشناسى، واحد كاشمر، دانشخاه آزاد اسلامى، كاشمر، ايران.

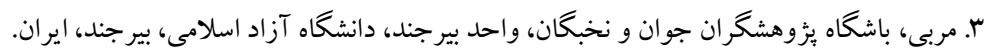

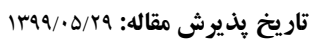

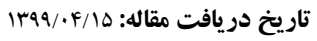

\section{جكيده}

مقدمه: كود كان مبتلا به اختلال طيف اوتيسم در مهارتهاى اجتماعى با مشكلات فراوانى روبهرو هستند.

هدف: هدف از اين يزوهش، بررسى اثربخشى آموزش تكتيككهاى رفتاردرمانى در بهبودى و افزايش ارتباط اجتماعى و تعامل اجتماعى در دانش آموزان درخودمانده بود.

روش: اين يزوهش با روش نيمه آزمايشى از نوع بيش آزمون- بس آزمون با يك گروه كنترل اجرا شد. جامعه آمارى شامل تمامى

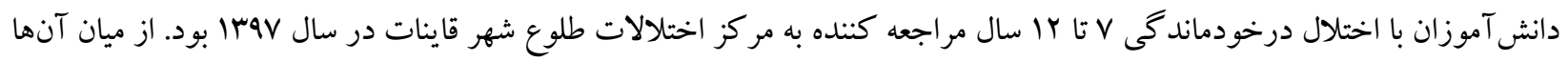

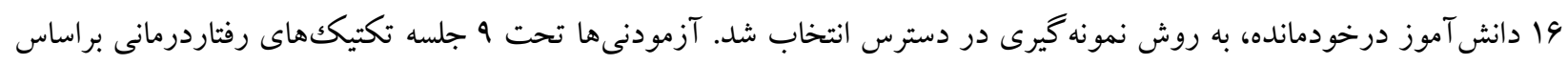

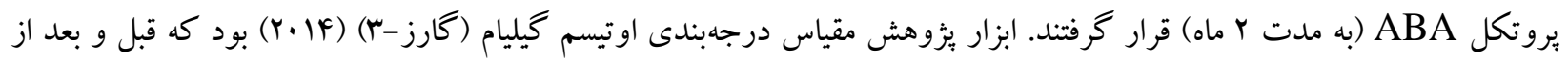

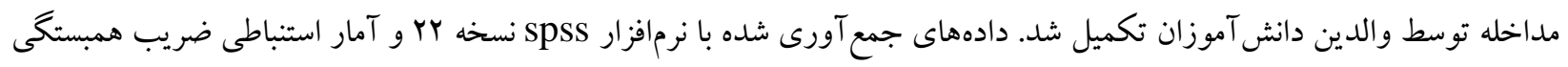
و آزمون t مورد تجزيه و تحليل قرار خرفت.

يافتهها: نتايج نشان داد كه تكتيككهاى رفتاردرمانى در بهبودى و افزايش ارتباط اجتماعى و تعامل اجتماعى در دانشآموزان

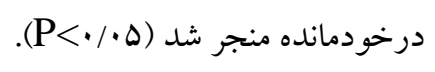

نتيجه كيرى: لذا مىتوان نتيجه گرفت كه تكتيكهاى رفتاردرمانى براى ارتقاى ظرفيت و بهبود دانش آموزان درخودمانده مىتواند

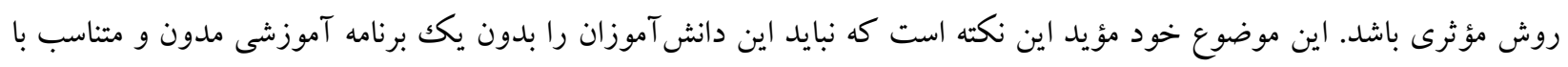
نيازهاى هر كودكى، به حال خود رها نمود. كليد وازها: تكتيككهاى رفتاردرمانى، ارتباط اجتماعى، تعامل اجتماعى، دانش آموزان درخودمانده 
درخودماندگى با آسيب كيفى در تعاملات اجتماعى به صورت كاربرد رفتارهاى غير كلامى، ناتوانى در برقرارى روابط مناسب با همسالان، فقدان تلاش در سهيم كردن ديخران در لذت، علائق و بيشرفتهاى خود و وقدان هندان تقابل اجتماعى يا هيجانى است (انجمن روانشناسى

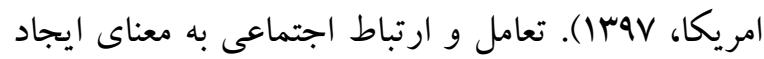
رابطه بين دو نفر يا بيشتر است كه منجر به واكنشى ميان افراد مىشود. همجينين تعامل اجتماعى و برقرارى ارتباط مى تواند يكك موضوع فيزيكى، يك نغاه، يك مكالمه و ارتباط بين افراد باشد كه خود مستلزم تعريف رويدادها و فعاليتهاى متناسب و درنتيجه نقش يذيرى افراد در فضا و عضويت آنها در گروهها و شبكههاى اجتماعى است

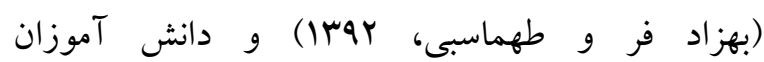
درخودمانده در اين تعاملات و ارتباطات اجتماعى دجار

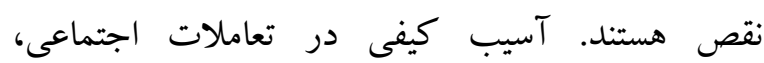
بهصورت تأخير يا فقدان كامل رشد زبان محاوره، استفاده از زبان كليشهاى و تكرارى يا زبان خاص به خود، فقدان تنوع در بازىهاى تخيلى خود به خودى، الخوهاى محدود تكرارى و كليشهاى و همجنين رفتار، علايق و فعاليتها، در قالب اشتغال ذهنى به يكك يا جند الكوى موردعلاقه و رفتارهاى حركتى تكرارى و كليشهاى و اشتغال ذهنى دائم با قسمتهاى اشيا نمايان مىشود

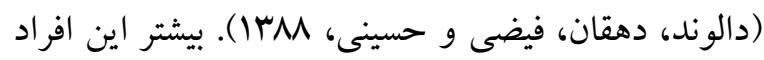
شيوع درخودماندگى و اختلالات مربوط به آن، ا نفر در هر 91 تولد زنده است (بهات، اجاريا، عادلى، بايرى و

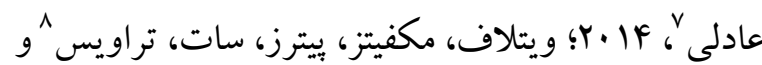

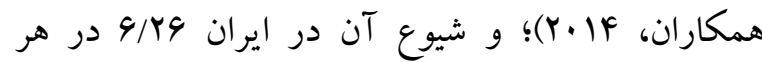

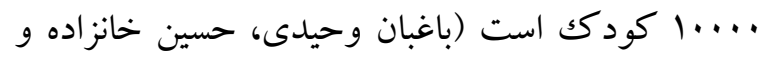

7- Bhat, Acharya, Adeli, Bairy \& Adeli

${ }^{8}$ - Weitlauf, Mcpheeters, Peters, Sathe \& Travis

\section{مقدمه}

يكى از مهمترين اختلالات فراگير رشد، اختلال

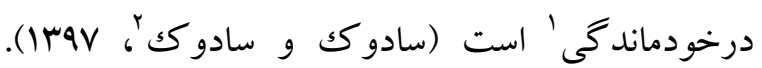
درخودماندگى به عنوان بخشى از طبقه كلى تر به عنوان

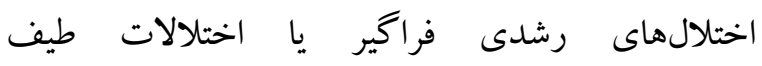
درخودماندگى در نظر گرفته مىشود. اين طبقه شامل هـ هـ اختلال زير است: اختلال درخودماندگىى، اختلال آسير گر، اختلال رشدى فراگير تصريح نشده، نشانگًان رت و اختلال از هم پياشيدكى كودكى (هالاهان و و

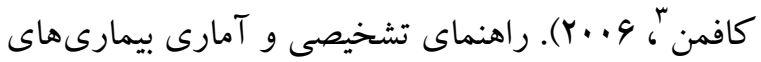

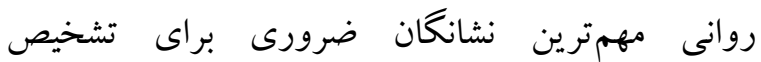
درخودماندگى را در سه حوزه خلاصه كرده است: نارسايىهاى اجتماعى، نارسايىهاى ارتباطى و الخُوهاى

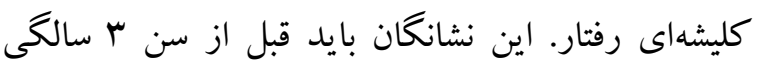
خود را نشان دهند تا تشخيص درخودماندگى داده شود

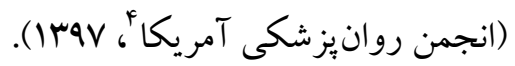

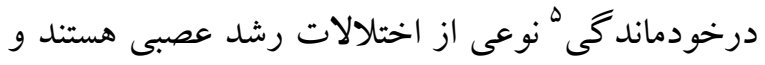

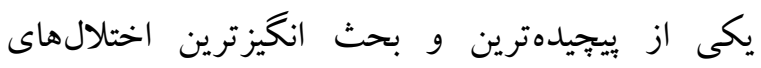
روانيزشكى بوده كه علائم و نشانهاى واحدى ندارد (قاسمى، امين يزدى و مشهلى، و9 1). در نسخه ينجم راهنماى تشخيصى و آمارى اختلالهاى روانى" ملاككهاى تشخيص درخودماندكى در سه حوزه خلاصه شدهاند كه عبارتاند از نارسايىهاى اجتماعى، نارسايىهاى ارتباطى و الخُوهاى كليشهاى رفتار. اين

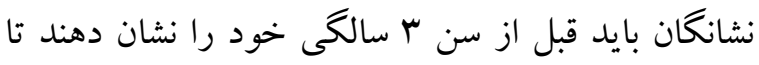

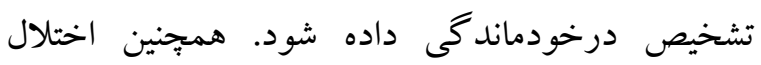

1- Autism

- Sadok \& Sadok

3. Hallahan \& Kauffman

4 - American Psychiatric Association

5 - Autism

- DSM-5 
عمده شرطى كردن فعال و شرطى كلاسيك يايه و اساس

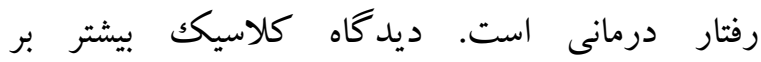
ياد گيرىهاى عاطفى تأكيد دارد و كاربرد آن در روان درمانى اصطلاحاً رفتار درمانى ناميده مىشود. از سوى ديخر كاربرد شرطى كردن فعال در رواندرمانى را تغيير رفتار مىنامند. علاوه بر اين دو ديدگاه نظريه يادگيرى اجتماعى و يا يادگيرىهاى مبتنى بر مشاهده، بخش مهم ديخرى را در سابقه رفتاردرمانى اشغال مى كند. در اين

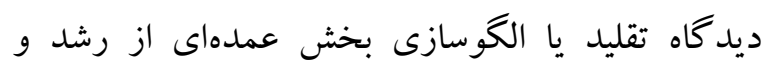
تكوين شخصيت است و تعدادى از تكنيكهاى رفتاردرمانى بر اصول اين نوع يادگيرى استوارند.

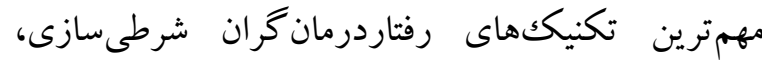
خاموش كردن يا حذف رفتار، آموزش متوقف كردن فكر، آموزش ابراز وجود، انزجار درمانى، حسابت زدايى منظم، شكل دادن به رفتار، الكوسازى و ايفاى نقش است. در واقع رفتار درمانگران رفتارى را كه بايد دگگ گون شود شناسايى مى كنند، به بررسى و شناسايى شرايطى كه رفتار را موجب شدهاند، موجبات ابقاء و ادامه رفتار را فراهم آوردهاند مىيردازند و در نهايت برنامههايى به منظور دگگ گونسازى و نيز يادگيرى رفتارهاى جديد تهيه و ارائه مىنمايند (قهارى، بهr|). از آنجا كه كودكان درخودمانده مشكل قابل توجهى در پِاسخ به حالتهاى عادى تجربهى اجتماعى و تعامل اجتماعى دارند؛ به همين دليل اين كودكان به حمايت و آموزش در زمينهى مهارتهاى اجتماعى نياز دارند تا بتوانند مهارتهاى لازم را كسب كنند. در واقع با آموزش مناسب و مداخلههاى اجتماعى و ارتباطى به اين كودكان مىتوان برخى از مهارتهاى كاربردى و مناسب را در آنان رشد دارد

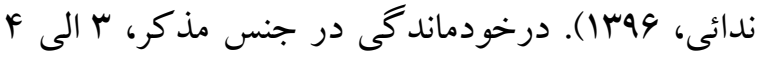
برابر شايعتر است؛ اما اختلال در دختران با عقب ماندگى لهى ذهنى شديدترى همراه است (محمدى جهرمى، اينالو و رئيسى، 94M (). اختلالات ادراكك و ارتباطات و يردازش حسى و عصبى در اين افراد به محدوديتهاى مختلف رفتار عملكردى در آنها منجر مىشود (ليويت بينون، داويدويتج و

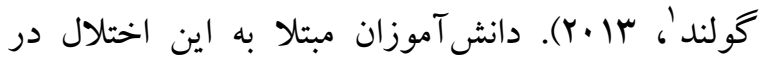

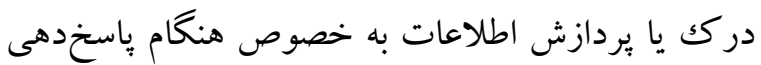
به موقعيتى بييجيده با مشكلاتى روبرو هستند (باغبان وحيدى و همكاران، 99 1). در حقيقت، اختلال در تعامل اجتماعى از نقايص اصلى كودكان درخودمانده است. بيشتر آنها قادر به ايفاى نقشهاى اجتماعى و مهارتهاى تجربى نبوده و در تجربيات ارتباطى نمى تو انند از ابزارهاى كلامى و نوشتارى استفاده كنند (خانَ'

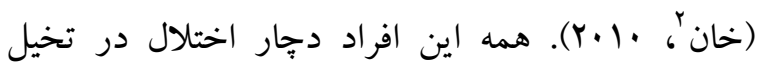
هستند و جهان براى آنها مكانى گيج كننده و كاهى آنى

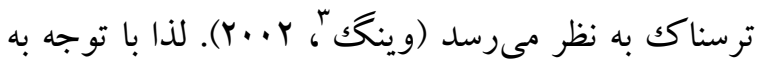
مطالب بيانشده دانش آموزان مبتلا به اختلالات درخودمانده براى ساز گارى در اجتماع و بهطور كلى تربيت نيازمند مراقبت هاى ويزه هستند (كومز، ليما، بوئنو،

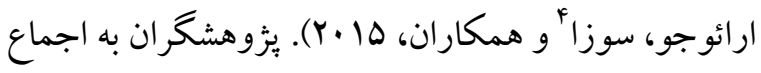
اجماع معتقدند كه مداخله زودهنگام براى اين گروه از دانش آموزان مفيد است (باغبان وحيدى و همكاران،

.11499

بنا بر مطالب بيان شده در اين تحقيق بر تكتيك هاى رفتار درمانى توجه شد. در تاريخجه رفتار درمانى دو ديد كاه

1- Levit-Binnun, Davidovitch \& Golland
2- Khan
3- Wing
4- Gomes, Lima, Bueno, Araújo \& Souza 
سال Vوس| بود. از اين جامعه آمارى تعداد 19 دانش آموز درخودمانده، به روش نمونه گيرى در دسترس انتخاب شد. از ملاككهاى ورود به تحقيق مىتوان به كسب نمره بالاتر از نقطه برش در خرده مقياسهاى تعامل اجتماعى و

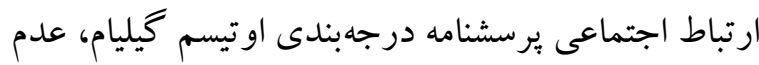
ابتلا به بيمارىهاى حاد روانى و جسمانى (بر اساس نظر روانشناس و روانيزشك)، تمايل به شركت در تحقيق، رضايت والدين دانش آموزان براى شركت فرزندانشان در تحقيق؛ ملاككهاى خروج از تحقيق، غيبت در يكى از

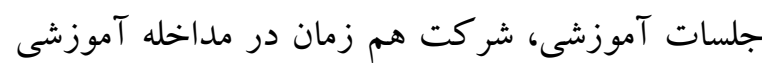
مشابه و عدم همكارى در يُزوهش را اشاره نمود. روش اجراى يُوهش بدين صورت بود كه يس از كسب

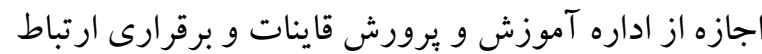
با كود كان اوتيسم و والدين آنها و ارائه توضيحات لازم در مورد هدف يثزوهش و جلب رضايت والدين آنها، تعداد 19 دانش آموز درخودمانده V-IY سال، به روش نمونه گيرى در دسترس انتخاب شد. در مرحله اول والدين اين دانشآموزان، مقياس درجهبندى اوتيسم كيليام

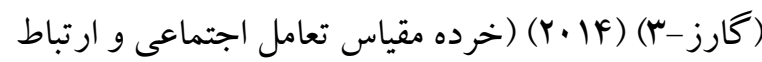

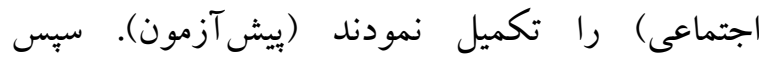
آزمودنىها تحت 9 جلسه تكتيككهاى رفتاردرمانى (به مدت Y ماه) قرار گرفتند. در بايان جلسات آموزش و بعد از كذشت يكك هفته مجدداً والدين به ابزار يثوهش باسخ دادند (يسآزمون)؛ كه خلاصه جلسات تكتيككهاى رفتاردرمانى در جدول آماده است:

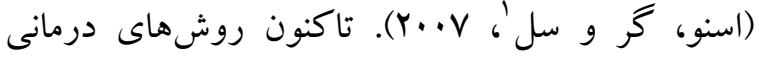
بسيارى براى كودكان با اختلال درخودماندگى ييشنهاد

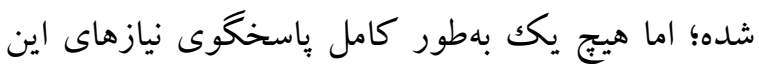

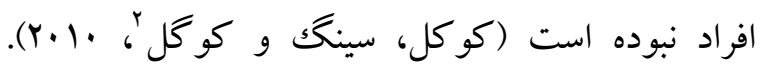

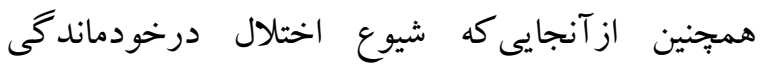
افزايش بيدا كرده به طورى كه امروزه از هر . 10 كودك، يكك كودكك اختلال درخودماندكى دارد (رنگانى، همتى علمدار لو، شجاعى و اصغرى نكاح،

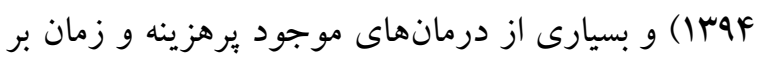
هستند، نياز به درمانهاى كمهزينهتر مانند تكتيككهاى

$$
\text { رفتاردرمانى احساس مىشود. }
$$

با توجه به مشكلات ارتباطى دانش آموزان درخودمانده و

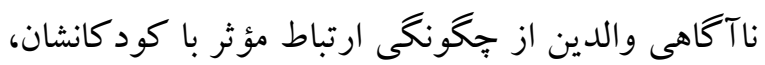
تلاش براى مداخلهى زود هنگام وآموزش ارتباط مؤثر به والدين كود كان درخودمانده به عنوان مهمترين شر كاى اجتماعى اين كودكان ضرورى به نظر مىرسد. با اين وجود، ئزوهشهاى اندكى در زمينهى تأثير اين شيوهها به صورت متمركز بر والدين، بر مهارتهاى اجتماعى كودكان درخودمانده به خصوص در ايران انجامشده است؛ بنابراين، مطالعه حاضر با هدف بررسى اثربخشى تكتيككهاى رفتاردرمانى در بهبودى ارتباط و تعامل اجتماعى در دانش آموزان درخودمانده انجام شد.

روش يثزوهش حاضر نيمه آزمايشى از نوع بيش آزمونبس آزمون با يكك گروه كنترل بود. جامعه آمارى شامل

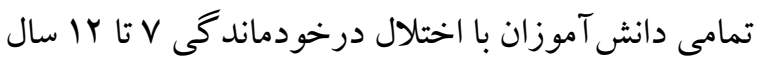
مراجعه كننده به مركز اختلالات طلوع شهر قاينات در

1. Snow, Gore \& Seale

2 - Koegel, Singh \& Koegel 
جدول ا خلاصه جلسات تكتيكىهاى رفتاردرمانى

\begin{tabular}{|c|c|}
\hline 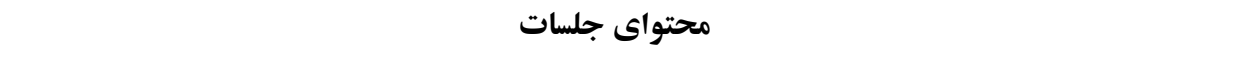 & جلسه \\
\hline معارفه، برقرارى ارتباط اوليه، مفهومسازى مجدد مسئله و ارزيابى اوليه ازلحاظ وضعيت روانشناختى & جلسه اول \\
\hline 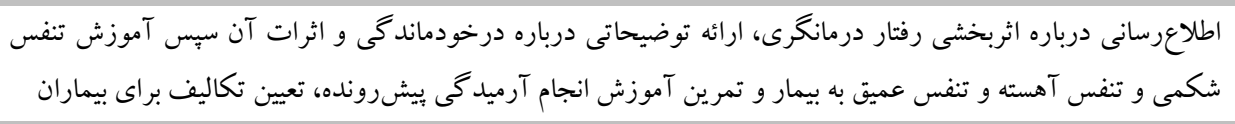 & 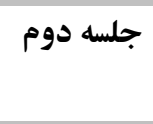 \\
\hline آموزش شناسايى افكار و رفتارهاى قالبى & 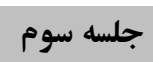 \\
\hline مرورى كو تاه بر جلسه قبلى، انجام آرامش عضلانى و تنفس عميق به مدت · ا دقيقه، آموزش جايكزينى رفتارهاى قالبى & 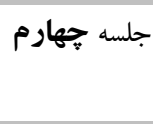 \\
\hline 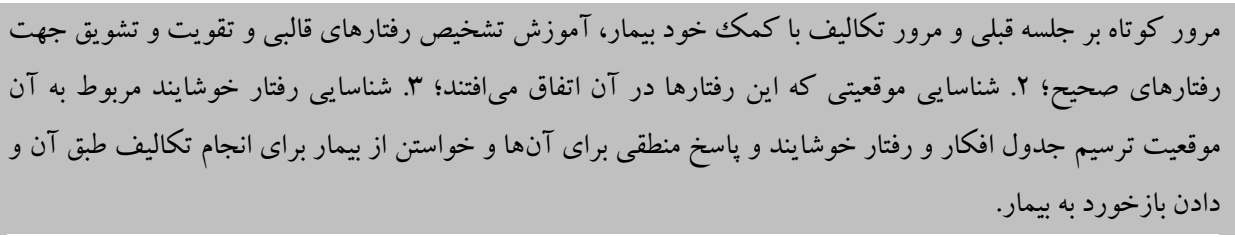 & جلسه ينجم \\
\hline 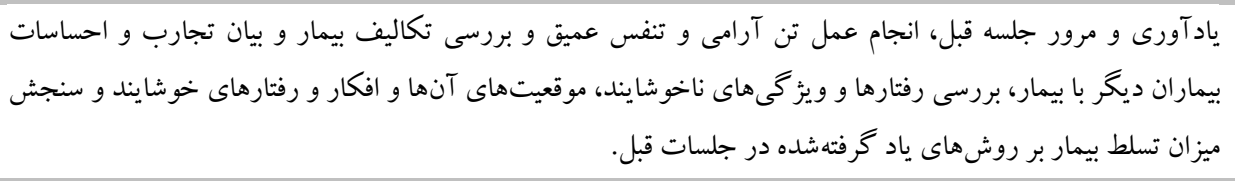 & جلسه ششم \\
\hline 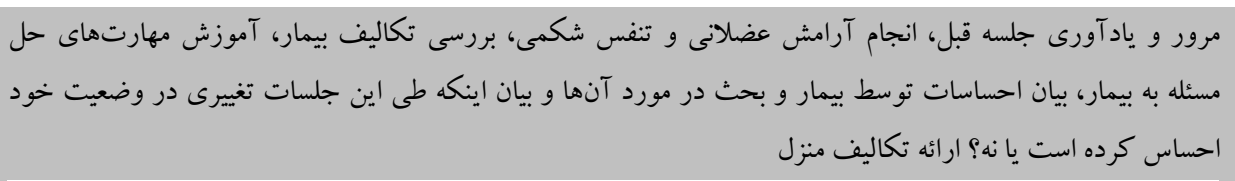 & جلسه هفتم \\
\hline 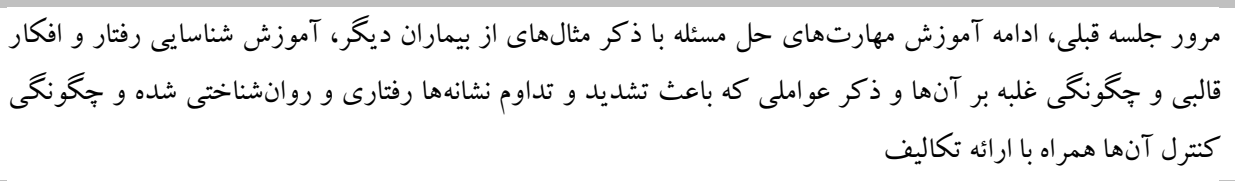 & جلسه هشتم \\
\hline و مرور كو تاه بر جلسه قبلى، اطمينان بخشى به بيمار مبنى بر سودمندى اين مهارت ها در برخورد با بيمارى و ساير مشكلات & جلسه نهم \\
\hline
\end{tabular}

است كه عبارتاند از: 1- رفتارهاى تكرارى / محدود كننده؛ ب- تعامل اجتماعى؛ ب- ارتباط اجتماعى؛ F- ياسخ هاى هيجانى؛ ه- سبك شناختى و و- كفتار ناساز گارانه. نتايج تحليل هاى كليام (Y) (Y) نشان مىدهد كه تمام شش خرده مقياس از اعتبار، روايى و حساسيت خوبى براى شناسايى افراد مبتلا به اوتيسم برخوردارند (مينائى و ناظرى، IM IV). تست گارز بر روى نمونهاى شامل ra.1 نفر از كودكان، نوجوانان و بزركتسالان جوان ايالت متحده آمريكا و كانادا مورد آزمايش قرارگرفته و استاندارد شده است (دقيقى، يوشنه و جعفرى، اهبا). قابليت اتكاء به آن با استفاده از تكنيك
دادههاى جمع آورى شده در دو بخش آمار توصيفى و آمار استنباطى ضريب همبستكى و آزمون t با نرمافزار نسخه Y SPSS ابزار ابزار اندازه كيرى در يُزوهش حاضر به شرح زير است: مقياس درجهبنلى اوتيسم تميليام' (تارز): اين مقياس كه

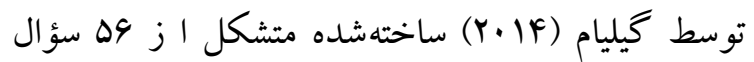
است كه در يكك مقياس جهار امتيازى ليكرت از • تا ب نمره كذارى مىشوند. كارز-ب داراى شش خرده مقياس

1. GARS-3 
استفاده از ضريب آلفاى كرونباخ محاسبه شد كه براى

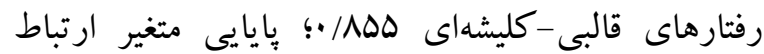
اجتماعى 919/ • و يايايى تعامل اجتماعى آمد. اين شاخصها نشاندهندهى اعتبار بسيار مطلوب "برسشنامهى گارز (كيليام) است. جهت محاسبه روايى، ازنظر روان شناسان و متخصصان استفاده گرديد. نتايج نشاندهنده اين است كه برسشنامه از روايى صورى و محتو ايى مطلوب و مناسب برخوردار است.

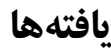
ئزوهش حاضر شامل 19 دانش آموز درخودمانده V-IY سال با ميانخين سنى 9/V و انحراف معيار 1/99 است. در جدول r ميانگين و انحراف معيار در نمرات ارتباط اجتماعى نشان دادهشده است.
آلفاى كرونباخ تعيين و مطالعات انجام شده نمايانكر ضريب آلفاى •9/· براى رفتارهاى كليشهاى، 91/ • براى ارتباط، سو/• براى تعامل اجتماعى، MA/ • براى اختلالات رشدى و 99/ • در نشانهشناسى درخودماندگى است. هم جنين طى مطالعهاى در آمريكا اعتبار و پِيايیى مقياس كارز بر روى ع Mا كودك درخودمانده انجام شد، نتايج ضريب اعتبار بالاى •ه/· را براى اين ابزار اعلام كرد

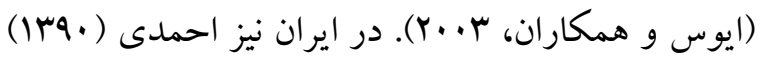
ضرايب همبستكى اين برسشنامه •^/ • به دستاوردند. مينايى و ناظرى (IrqV) نيز نشان دادند خرده مقياسها و همجنين كل مقياس كارز-ب از اعتبار بالايى برخوردارند. همجنين شواهد حاصل از منابع و تحليلهاى مختلف

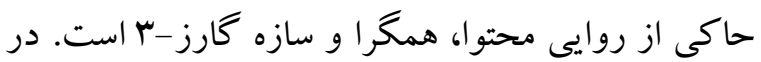
ئزوهش حاضر، بايايى هريك از متغيرهاى ئزوهش با

\begin{tabular}{|c|c|c|c|}
\hline خطاى انحر اف ميانكين & انحر افمعيار & ميانتين & كروه آزمايش \\
\hline r/ه৭9 & $1 \cdot / \pi \wedge \Delta$ & YY/IYD & ي پيش آزمون \\
\hline $\mathrm{r} / \mathrm{A} \cdot \mathrm{V}$ & $11 / \pi r$. & 19/AVD & پِ آزمون \\
\hline
\end{tabular}

آزمون كولمو گوروف-اسميرنوف براى نمرات ارتباط

اجتماعى در بيش آزمون و يس آزمون در جدول ب نشان داده است.
جدول r، ميانگين و انحراف معيار ارتباط اجتماعى در

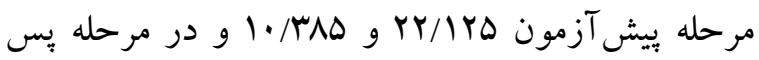

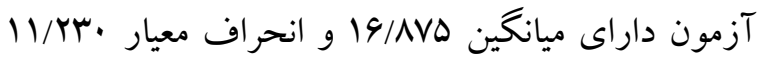
است. با توجه به اين اطلاعات، توزيع متقارن است. نتايج

جدول ب نتايج آزمون كولمو كوروف- اسميرنوف براى نمرات ارتباط اجتماعى در ييش آزمون و يس آزمون

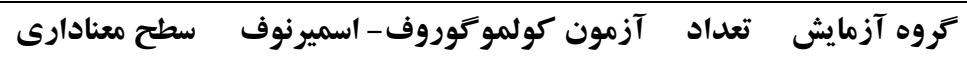

\begin{tabular}{|c|c|c|c|}
\hline$\cdot / 9 V F$ & . /VYr & 19 & ييش آزمون \\
\hline$\cdot / ৭ \wedge \vee$ &.$/ 4 \Delta$ & 19 & پֶ آزمون \\
\hline
\end{tabular}


همبستكى مثبت و معنادارى وجود دارد. نتايج تحليل

$$
\begin{aligned}
& \text { بر اساس نتايج آزمون كولمو گوروف- اسميرنوف جون }
\end{aligned}
$$

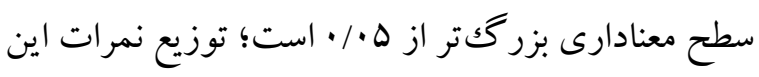

$$
\begin{aligned}
& \text { متغير نرمال است. } \\
& \text { نتايج آزمون همبستكى نشان مىدهد كه بين بيش آزمون }
\end{aligned}
$$

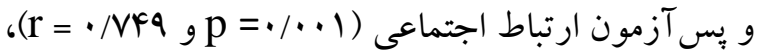$$
\text { آزمون و بس آزمون در جدول F ارائه شده است. }
$$

\begin{tabular}{|c|c|c|c|c|c|c|c|c|c|}
\hline معنادارى سطح & دراجه & $\mathbf{T}$ & 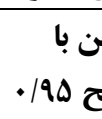 & اطمينان & خطاى معيار & انحراف & تفاوت & تعداد & كروه آزمايش \\
\hline \multirow[t]{2}{*}{$.1 \cdot 19$} & \multirow[t]{2}{*}{10} & \multirow[t]{2}{*}{ Y/VYA } & بالا & پِايين & \multirow[t]{2}{*}{ l/AYF } & \multirow[t]{2}{*}{$V / 991$} & \multirow[t]{2}{*}{$\Delta / r \Delta}$. & \multirow[t]{2}{*}{19} & \multirow[t]{2}{*}{ ييش آزمون - يس آزمون } \\
\hline & & & $Q / r \Delta r$ & I/IFV & & & & & \\
\hline
\end{tabular}

جدول ^ نتايج تحليل آمارى آزمون T همبسته براى مقايسه نمرات بيش آزمون و پِّآزمون در ارتباط اجتماعى

ميانگين نمرات تفاوت بيش آزمون و بِ بس آزمون ارتباط

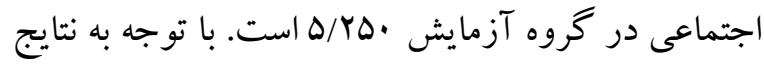
تحليل آمارى مى توان نتيجه گرفت كه تكتيككهاى رفتار درمانى باعث بهبودى ارتباط اجتماعى دانش آموزان درخودمانده مىشود. در جدول ه، ميانگين و انحراف معيار نمرات تعامل اجتماعى نشان داده شده است.
نتايج جدول Fٔ تحليل آمارى مقايسه ميانكين نمرات بيش آزمون و يس آزمون ارتباط اجتماعى نمايش داده مىشود. هنگامى كه نمرات بيش آزمون و وِّ آزمون ارتباط اجتماعى از طريق آزمون T همبسته مورد بررسى قرار گرفت، نتايج نشان داد كه ميانگين نمرات ارتباط اجتماعى در مرحله ييش آزمون و بِ آزمون ازنظر آمارى معنادار شده است (19 (19

\begin{tabular}{|c|c|c|c|}
\hline$r / 90 \mathrm{~V}$ & 1.1949 & $r 1 / .9 r$ & بيش آزمون \\
\hline r/gFt & $1 \cdot / \Delta V$ & $\mid r / \ldots$ & ֶׁ آزمون \\
\hline
\end{tabular}

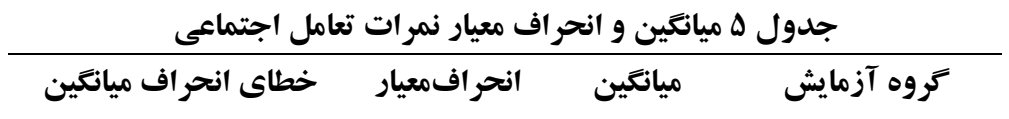

كه ميانگين تعامل اجتماعى در بيش آزمون بالاتر از يس آزمون است. نتايج نشان مىدهد كه آموزش تكنيكهاى رفتارى (9 جلسهى .4 دقيقهاى در طى r ماه) توانسته، تعامل اجتماعى هر يك از دانش آموزان را بهبود بخشد. بر اساس نتايج آزمون كولمو گوروف- اسميرنوف براى نمرات تعامل اجتماعى در بيش آزمون و بِ بسآزمون
در جدول ه، ميانگين تعامل اجتماعى در مرحله

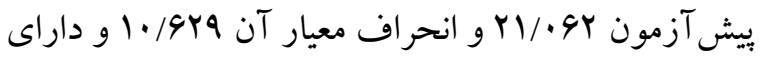
جولكى و كشيدگى منفى و در مرحله يس آزمون داراى

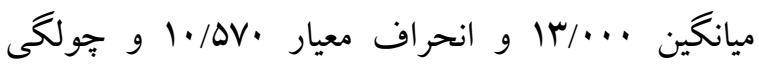
مثبت و كشيدگى منفى است. با توجه به اين اطلاعات، توزيع متقارن است. نتايج حاصل از جدول نشان مىدهد 


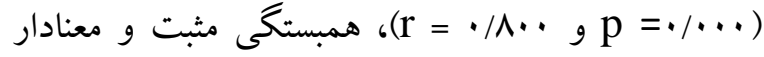
وجود دارد. نتايج تحليل آمارى آزمون T براى مقايسه نمرات تعامل اجتماعى در بيش آزمون و بِ بـ آزمون در جدول 9 ارائه شده است.
جون سطح معنادارى بزرگكتر از ه•/ است؛ توزيع نمرات اين متغيرها نرمال است. نتايج ضريب همبستكى تعامل اجتماعى در بيش آزمون و يس آزمون نشان مىدهد

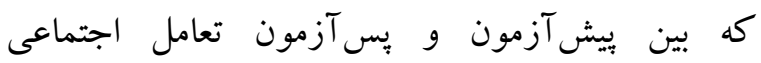

\begin{tabular}{|c|c|c|c|c|c|c|c|c|c|}
\hline معنادارى سطح & آزادى درجه & $\mathbf{T}$ & $\begin{array}{r}\text { | } \\
\text { | }\end{array}$ & تفاوت ميانً & خطاى معيار & انحراف & تفاوت & تعداد & كروه آزمايش \\
\hline \multirow[t]{2}{*}{$\cdot / \cdots$} & 10 & $r / \Lambda \cdot \Lambda$ & بالا & هايين & $1 / 9 \vee 9$ & $9 / \mathrm{V} \cdot \mathrm{V}$ & $N / \cdot 9 r$ & 19 & ييش آزمون - يس آزمون \\
\hline & & & $11 / 949$ & $F / F M$ & & & & & \\
\hline
\end{tabular}

بهبودى و افزايش ارتباط اجتماعى و تعامل اجتماعى دانش آموزان درخودمانده مؤثر است. نتايج اين يزوهش با نتايج تحقيقات يوشنه و صيام يور (سوس|)؛ بيرمىنيا و مظفرى تو كلى (هوس|)؛ بهمنى، نعيمى و رضايى (IMQVV) همسو و همخوان است. سيزو و كويبر' (Y.IV) نيز در تحقيقى نشان داد كه فنون رفتارى روش اصلى درمان رفتار نابهنجار در كودكان مبتلا به

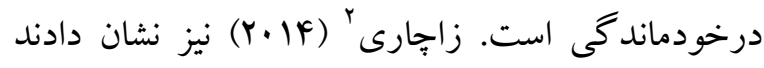
مداخلات رفتارى در دانش آموزان درخودمانده باعث كاهش درشدت درخودماندگى، رشد در سطوح شناختى ملى و انطباقى مىشود؛ كه مطابق و هم جهت با نتايج اين

$$
\text { ئزوهش است. }
$$

مشخصه درخودماندگى، محدوديت شديد و بنيادى در جندين زمينه مهم رشد مانند تعامل و ارتباط و همبِنين رفتار متقابل اجتماعى و توانايى بهره گيرى از تخيلات است. دشوارى در تعامل متقابل اجتماعى اغلب قابل توجهترين جنبه اوتيسم است. بسيارى از كود كان مبتلابه اوتيسم هيج گونه رابطة متقابل احساسى يا اجتماعى از
جدول 9، نتايج تحليل آمارى مقايسه ميانكين نمرات ييش آزمون و يس آزمون تعامل اجتماعى نمايش داده مىشود. هنگامى كه نمرات بيش آزمون و و بس آزمون تعامل اجتماعى از طريق آزمون T همبسته مورد بررسى قرار گرفت، نتايج نشان داد كه ميانگين نمرات تعامل اجتماعى در مرحله بيش آزمون و بس آزمون ازنظر آمارى

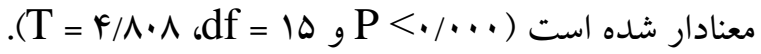
ميانگين نمرات تفاوت ييش آزمون و يسآزمون تعامل

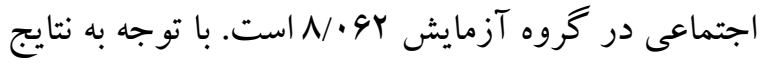
تحليل آمارى مى توان نتيجه گرفت كه تكتيككهاى رفتار درمانى باعث بهبودى تعامل اجتماعى دانش آموزان درخودمانده مى شود. ئزوهش حاضر با هدف بررسى اثربخشى آموزش تكتيككهاى رفتاردرمانى در بهبودى و افزايش ارتباط اجتماعى و تعامل اجتماعى دانش آموزان درخودمانده انجام شد. نتايج نشان داد كه تكتيككهاى رفتاردرمانى در

1- Sizoo \& Kuiper

${ }^{2}$ - Zachary 


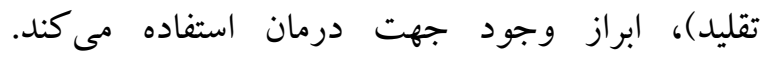
رفتاردرمانى با درگير سازى كودك به انجام فعاليتهاى مفرح با در اختيار گرفتن فضاى درمانى، توجه را به برقرارى ارتباط متمركز كرده و در طى بـ اين فرايند رفتارهاى كليشهاى كودك در زمان رفتاردرمانى جهت يافته و در مسيرى هدايت مىشود و كودكك با آرامش و اعتماد به نقش بيشترى به فعاليت مى يردازد و در نتيجه به

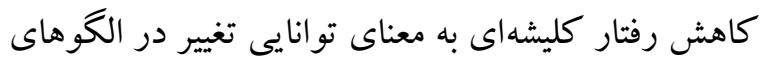
روزمره زندگىى، كنترل رفتار منجر مىشود. همجينين كودكك با درگير شدن با اين روش از طريق بازىها و فعاليتهاى تقليدى متقابل كودكك در تعامل اجتماعى با طرف متقابل خود قرار مى گيرد و اين گونه تبادلات موجب ايجاد فرصتهايى مىشود كه دو طرف مىتواند در طول برقرارى ارتباط كفتارى با هم استفاده نمايند و اين راهبرد مهم و اثر گذار در گسترش واز گان كود كان محسوب مىشود و مىتواند با افزايش مهارتهاى ارتباطى روبرو شود (يوشنه و همكاران، سوسا). در تبيين اين فرضيه مىتوان كفت دانش آموزان درخودمانده مشكلات زيادى را در زمينهاى ارتباط كلامى و و غير كلامى، تعامل اجتماعى يا باسخدهى اجتماعى و همجنين فعاليتهاى محدود شده، تكرارى و قالبى دارند.

\section{نتيجه كيرى}

با توجه به اين كه دانش آموزان درخودمانده در اين زمينه ها دجار آسيب و نقص مىباشند و از طريق آموزش در كنترل رفتارهاى آسيبرسان آنها مىتوان بهبودى آنى حاصل كرد، لذا آنها خواهند توانست خود را با محيط سازش داده و از روابط مفيد و انسانى و اجتماعى برخوردار شوند. دانشآموزان درخودمانده در سايهى
خود نشان نمىدهند و به شكل خودانكيخته در شادى هاى خود با والدين شريك نمى شوند يا براى راحتى آنها را بروز نمىدهند. كود كان مبتلا به اوتيسم هميشه به كود كان هم سن خود علاقه نشان نمىدهند؛ اما حتى اكر علاقه نيز نشان دهند معمولاً در دوستيابى و حفظ دوستان خود دجار مشكل مىباشند. افراد مبتلابه اوتيسم براى توانايى حرف زدن دجار تأخير مىباشند يا فاقد آن هستند و آن را با استفاده از ديخر راههاى غير كلامى برقرارى ارتباط جبران نمى كنند. اين در صورتى است كه بسيارى از كود كان مبتلا به درخودماندگى مى تونى انتد با تلاشهاى آموزشى زود هنگام، درست برنامهريزى شده و طراحى شده براى هر فرد در يكك محيط مناسب ويزه رشد قابل ملاحظهاى داشته باشند؛ و يكى از اهداف اصلى كمكك به كودكك براى تكامل برقرارى ارتباط و

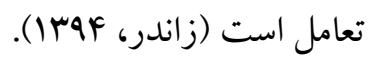
رفتاردرمانى نام مجموعهاى از انواع روشهاى درمانى است كه در درمان اختلالات ذهنى مورد استفاده قرار مى گيرند. اين نوع درمان براى شناسايى و كمكك به تغيير رفتارهاى ناسالم يا خود تخريبى بالقوه و نهادينه در فرد به كار مىرود. رفتاردرمانى بر اساس اين نظريه عمل مى كند

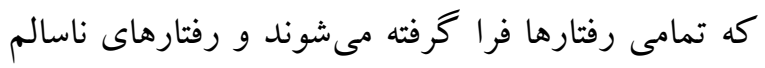
مىتوانند تغيير بيدا كنند. تمر كز اين نوع درمان اغلب بر مشكلات جارى و جّكونكى تغيير دادن آنها است. رفتاردرمانى روشهاى متفاوتى براى بِاسخ مثبت دادن به

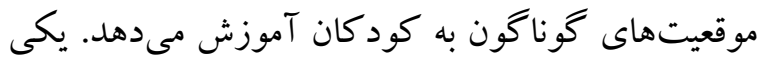
از بخشهاى اصلى اين روش عبارت است از جايزه دادن به رفتار مثبت و تنبيه كردن رفتار منفى. همجنين رفتاردرمانى از تكنيككهايى مانند حساسيتزدايى منظم، آراميدگى، مواجهه درمانى، تمرين رفتارى (ايفاى نقش، 


\section{References}

Ahmadi S, Safari T, Hemmatian M, Khalili Z (2011). The Psychometric Properties of Gilliam Autism Rating Scale (GARS). Research in Cognitive and Behavioral Sciences, 1(1), 87104.

American Psychiatric Association. (2018). Diagnostic and Statistical Manual of Mental Disorders. Translated by Farzin Rezaei et al., Tehran: Arjmand Publications. (In persian)

Baghban-Vahidy M, Hossein Khanzadeh AA, Nedaei N. (2017). The effect of effective communication skills training on mothers of children with autism on improving their children's social skills. Joumal of Disability Studies, 7, 1-7. (In persian)

Bahmani M, Naeemi E, \& Rezaei S. (2018). The effectiveness of cognitive-behavioral games intervention program on social and emotional skills of children with autism with high performance. Clinical Psychology Studies, 8 (31), 176-157. (In persian)

Behzadfar M, Tahmasebi A. (2013). Identify and evaluate the components that affect social interactions, consolidation and development of citizenship relations in urban streets. Nazar Garden, 25 (10), 17-28. (In persian)

Bhat S, Acharya U, Adeli H, Bairy G, Adeli A. (2014). Autism: cause factors, early diagnosis and therapies.Rev Neurosci, 25(6): 841-50.

Birmini Nia S, Manzari Tavakoli V. (2016). The effectiveness of cognitive-behavioral play therapy in the social anxiety of children with autism. Second National Conference on New Research in Humanities and Social Studies of Iran, 1-4. (In persian)

Dalvand H, Dehghan L, Faizi A, \& Hosseini SA. (2009). Investigating the effect of homeopathic lavage treatment approach on improving social interactions, speech and language, play and behavioral skills, and the severity of childhood illness. New Rehabilitation, Tehran University of Medical Sciences, 3 (1 and 2), 12-16. (In persian)
برنامهى آموزشى تا حدودى مىتوانند به زندگى كاملتر و از نظر شخصى رضايت بخشترى دست يابند؛ آنها مىتوانند شناخت بهترى از مسائل خود به دست آورده و ساز گارى بيشترى از خود نشان دهند؛ ازنظر اجتماعى تا حدودى ييشرفت كنند. اين امور خود موجب ساز كارى مطلوب و توانمند شدن فرد براى زندگى شادتر و سالمتر مىشود. زمانى كه يكى كودكى درخودمانده با آموزش مناسب بر رفتار خود كنترل بيدا كند قادر خواهد بود با موقعيتهاى مختلف سازش بهترى بيدا كند. اين نتايج با مطالعات صورت گرفته در اين زمينه همخوانى دارد كه دانش آموزان درخودمانده با يكك برنامه منظم و تدوين شده با شرايط آنان موفقيت بيشترى كسب مى كنند. يُوهش حاضر از برخى جهات با محدوديتهايى مواجه بوده است كه از جمله بارزترين آن مىتوان به اين نكته اشاره داشت كه حفظ رفتار ارتباطى و تعامل اجتماعى به تقويت بيوسته برخى وِاسخهاى رفتارى بستگى دارد و

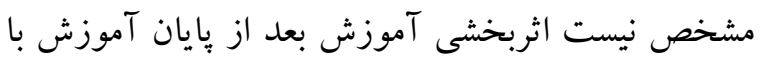
تكتيككهاى رفتاردرمانى تداوم داشته يا خير. لذا به يثزوهشخران آينده بيشنهاد مىشود كه تأثير تكتيككاى رفتاردرمانى را در مقايسه با ساير روشهاى درمانى در درمان درخودماندگى مورد مطالعه قرار دهند. همجينين ييشنهاد مىشود تا معلمان اين دانش آموزان با نظارت روانشناس متخصص امر در برنامهى آموزشى خود تغييرات لازم را ايجاد نمايند و از نتايج اين يثزوهش در آموزش هاى خود بهره بيرند.

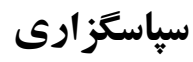

از مادران و كودكان عزيزى كه در انجام اين ئزوشش نهايت همكارى را داشتند، بسيار سِاسگزاريم. 
Dehkordi AA, Alipour A, Zare H, Shahidi GA, \& Barghi Irani Z (2013). Effectiveness of Elderly Behavior Therapy on General Health Components of Parkinson's Disease. Quarterly Journal of Modem Psychological Research, 8 (30), 97-122. (In persian)

Eaves L, Silberg J, Erkanli A. (2003). Resolving multiple epigenetic pathways to adolescent depression. Joumal of Child Psychology \& Psychiatry, 44(7), 1006-1014.

Ghahari Sh. (2015). Behavioral therapy techniques. Tehran: Qatreh Publications. (In persian)

Ghasemi S, Amin Yazdi SA, Mashhadi A. (2017). Preliminary study of the effectiveness of the evolutionary model of individual differences based on the relationship between improved language acquisition in children with autism spectrum disorder. Joumal of Exceptional Children, 17 (2), 88-96. (In persian)

Gomes PTM, Lima LHL, Bueno MKG, Araújo LA, Souza NM, Gomes PTM. (2015). Autism in Brazil: a systematic review of family challenges and coping strategies. Jomal de Pediatria, 91(2), 111-21.

Hallahan D, Kauffman J. (2006). Exceptional leamers: introduction to special education.

Kahrazi F, Danesh E, Haidarzadegan A. (2012). The effectiveness of cognitive therapy behavior in reducing the psychological symptoms of cancer patients. Zahedan Medical Sciences Research Journal, 14 (2), 112-116. (In persian)

Khan TM. (2010).The effects of multimedia learning on children with different special education needs. ProcediaSoc Behav Sci, 2(2), 4341-5.

Koegel LK, Singh AK, Koegel RL. (2010). Improving motivation for academics in children with Autistic. Joumal of Autistic Developmental Disorder, 40(4), 57-66.

Levit-Binnun N, Davidovitch M, Golland Y. (2013). Sensory and motor secondary symptoms as indicators of brain vulnerability. J Neurodev Disord, 5(1),26.

Minaei A, Nazeri S. (2018). Gilliam Autism - Third Edition (Garz-3) in People with Autism: A Preliminary Study. Joumal of Exceptional Children, 18 (2), 113-122. (In persian)
Mohammadi-Jahromi L, Inalo S, Reisi H. (2017). Investigating the prevalence of autism in children with epilepsy who refer to Imam Reza Clinic and compare it with the control group (non-epileptic children with epilepsy). Joumal of Shahid Sadoughi University of Medical Sciences, Yazd, 25 (3), 170-162. (In persian)

Pushneh K, Siampour N, Abedi M. (2014). The effect of cross-imitation training method on improving children's symptoms with autism. Quarterly Journal of Exceptional People, 4(16), 1-19. (In persian)

Rangani A, Hemmati-Alamdar G, Shojaei S, Asghari N. (2015). The effectiveness of puppet play therapy intervention on the social skills of male students with autism. Joumal of Exceptional Psychology, 5 (20), 73-92. (In persian)

Sadok, Benjamin James and Sadok, Virginia E. (2018). Psychological Summary of Behavioral Sciences / Clinical Psychiatry, translated by Farzin Rezaei, Tehran: Arjmand Publications. (In persian)

Sizoo BB, Kuiper E. (2017). Cognitive behavioural therapy and mindfulness based stress reduction may be equally effective in reducing anxiety and depression in adults with autism spectrum disorders. Res Dev Disabil, 64, 4755.

Snow MS, Gore B, Seale HA. (2007). A comparison of behaviors and play themes over a six-week period: Two case studies in play therapy. International Journal of PlayTherapy, 16, 147159.

Weitlauf AS, Mcpheeters ML, Peters B, Sathe N, Travis R, Aiello R, et al. (2014). Therapies for children with Autism Spectrum Disorder. Behavioral Interventions Update. Agency for Health care Research and Quality.

Wing L. (2002). The Autistic Spectrum: A Guide for Parents and Professionals. Robinson.

Zachary W. (2014). Therapies for Children With Autism Spectrum Disorders. Comparative Effectiveness Reviews, 26.

Zander E. (2016). Introduction to Autism. Translated by Behnam Kliki, Tehran. (In persian) 